UDC 339.13(4-672EU) ; 340.142:341.645(4-672EU)

CERIF: S150

DOI: $10.5937 / A n a l i P F B 1804084 S$

Vladimir Savković, $\mathrm{PhD}^{*}$

\title{
DO TFEU PROVISIONS ON FREE MOVEMENT OF GOODS APPLY TO PRIVATE PARTIES - EXPANDED VERTICAL OR HORIZONTAL DIRECT EFFECT?
}

The paper aims to establish whether and to what extent the TFEU provisions on free movement of goods apply to legal relations established between two or more private parties. To that end, a stringent analysis of the case law related to this particular issue is provided, aimed at supporting the initial hypotheses that, notwithstanding sporadic but only implicit inclination in its judgments towards establishing the direct horizontal effect of the free movement of goods, the CJEU has constantly and resolutely abstained from recognizing the existence of such an effect - the same effect that it acknowledged decades ago, regarding the free movement of workers and freedom to provide services. Before this analysis, overview is provided of the status quo regarding the horizontal direct effect of the free movement of workers and services, which was needed not only for understanding the differences in the CJEU's approach to various fundamental freedoms but also to outline the general framework in which the horizontal direct effect of fundamental freedoms currently exists, too. Finally, based on the case law analysis, the conclusion is offered that in terms of the recent developments in the field of free movement of goods the CJEU has opted for further expansion of the concept of vertical direct effect in order to both avoid establishing the horizontal direct effect of the freedom of movement of goods and safeguard the functioning of internal market against certain impediments generated by private parties.

Key words: $\quad$ Free movement of goods. - Vertical direct effect. - Horizontal direct effect. - Private parties. - CJEU case law. ac.me.

Associate Professor, University of Montenegro Faculty of Law, vladimirs@ucg. 


\section{INTRODUCTION}

\subsection{Judicial activism of the CJEU and (horizontal) direct effect of TFEU free movement provisions as its consequence}

It seems today as if the Court of Justice of the European Union (CJEU) has always been known not only for applying contemporary EU law but also for creating new rules and legal concepts of EU law by creatively interpreting existing ones. The proponents of such perception of the CJEU's mandate - as well as of acting in accordance with it would say that the court was virtually obliged to do so in order to correct the shortcomings inherent to European legislature, whereas the opponents of this so-called "judicial activism of the CJEU" would say that these were and still are clear examples of an overstepping of the court's mandate. ${ }^{1}$ Be that as it may, it also seems that for the past five decades the CJEU has predominantly relied on the one single doctrine in order to justify the gradual extension of its own "regulatory reach". This is, of course, the doctrine underlying the effet utile rule of interpretation, i.e. the principle of effectiveness of EU law, referred to as the "meta-rule" of interpretation of the CJEU even by the ones questioning its justifiability in the said context and disapproving its regular implementation, ${ }^{2}$ which allowed the court to (creatively) interpret any regulation, with the aim of achieving its best possible effect. Therefore, for more than half a century it has stood as an efficient tool in the hands of the European judges, repeatedly utilized to gradually institute "big, long-term policy changes through a series of low-visibility events." ${ }^{3}$ Arguably the two most

1 There are numerous academic papers and other sorts of academic literature published on the general topic of the judicial activism of the CJEU and fundamental changes in EU law resulting from it. For this reason, only a lesser part is referenced hereinafter. See, e.g., J. H. H. Weiler, "The Court of Justice On Trial", Common Market Law Review 24/1987, 555-589; T. Tridimas, "The Court of Justice and Judicial Activism", European Law Review 21/1996, 199-210; T. C. Hartley, "The European Court, Judicial Objectivity and the Constitution of the European Union", The Law Quarterly Review 112/1996, 95-109; A. Arnull, "The European Court and Judicial Objectivity: A Reply to Professor Hartley", The Law Quarterly Review 112/1996, 411-423; De Freitas L. V., "The Judicial Activism of the European Court of Justice", Judicial Activism: An Interdisciplinary Approach to the American and European Experiences (eds. L. P. Coutinho, M. La Torre, S. D. Smith), Springer International Publishing, Cham - Heidelberg 2015, 173-180; E. Muir, M. Dawson, B. de Witte, "Introduction: The European Court of Justice as a Political Actor", Judicial Activism at the European Court of Justice (eds. M. Dawson, B. de Witte, E. Muir), Edward Elgar Publishing, 2017, 1-10; M. Blauberger, S. K. Schmidt, "The European Court of Justice and its political impact", West European Politics40(4)/2017, 907-918.

2 See, e.g., S. Mayr, "Putting a Leash on the Court of Justice? Preconceptions in National Methodology v Effet Utile as a Meta-Rule", European Journal of Legal Studies $5(2) / 2012,7-21$.

3 This is, in fact, one of the possible definitions of the so-called "incrementalism" in the CJEU approach to introducing new legal rules and legal concepts into the existing 
significant cases decided by the CJEU in this regard were Van Gend \& Loos, ${ }^{4}$ the case establishing the principle and the underlying doctrine of direct effect of the EU law, and Costa v. ENEL, ${ }^{5}$ which inaugurated the second key principle of EU law: the principle of its supremacy over national legal orders. ${ }^{6}$

The principle of supremacy (primacy) of EU law over national legal orders is not in the primary focus of this paper; ${ }^{7}$ however, the principle of direct effect of EU law is at the centre of it. Namely, with its judgment in Van Gend \& Loos the CJEU achieved that, from then onwards, private physical or legal persons from any Member State could rely on certain provisions of EU law - the number of which is constantly being enlarged ${ }^{8}-$ to regulate legal relations between such persons and one of the Member States. ${ }^{9}$

legal order, so as to render it more functional and efficient. See M. Shapiro, "The European Court of Justice", The Evolution of EU Law (eds. P. Craig, G. De Búrca), Oxford University Press, Oxford 1999, 324. For a more detailed and more contemporary discussion on the notion of the CJEU's incrementalism in implementing EU law, see U. Sadl, "The Role of Effet Utile In Preserving the Continuity and Authority of European Union Law: Evidence From the Citation Web of the Pre-accession Case Law of the Court Of Justice of the EU”, European Journal of Legal Studies 8(1)/2015, 18-45.

4 Case 26/62, NV Algemene Transport-en Expeditie Onderneming van Gend \& Loos v Netherlands Inland Revenue Administration (5 February 1963) EU:C:1963:1.

5 Case 6/64, Flaminio Costa v E.N.E.L. (15 July 1964) EU:C:1964:66.

6 In one of the most inspiring descriptions of the significance of these two cases, decided by the CJEU, de Waele wrote that these two cases "are universally thought to be the twin pristine heralds of a court treading higher ground, leaving behind traditional conceptions of what international judges do and are capable of." See H. de Waele, "The Role of the European Court of Justice in the Integration Process: A Contemporary and Normative Assessment", Hanse Law Review 6(1)/2010, 1-26;

7 On the other hand, it should be underlined that these two principles are interdependent in so many different ways, particularly so in the context of the indirect effect of EU law, as well as in the context of horizontal direct effect, which is a further variation of the initial notion of direct effect and represents a subject of primary concern in this paper. See, e.g., R. van Leuken, Private Law and the Internal Market: Direct Horizontal Effect of the Treaty Provisions on Free Movement, Intersentia, Cambridge 2017, 21.

8 Furthermore, there is evidence today that not only certain written rules but also the non-codified principles of EU law have been recognized as having horizontal direct effect. See M. de Mol, "Kücükdeveci: Mangold Revisited - Horizontal Direct Effect of a General Principle of EU Law: Court of Justice of the European Union (Grand Chamber) Judgment of 19 January 2010, Case C-555/07”, European Constitutional Law Review 6(2)/2010, 293-308.

9 For more detailed elaboration of Van Gend and Loos and its consequences on the future development of EU law, for instance, see T. Storey, C. Turner, Unlocking Company Law, Routledge, Abingdon, Oxon - New York 2014 ${ }^{4}$, 153; M. Rasmussen, "Revolutionizing European law: A history of the Van Gend en Loos judgment", International Journal of Constitutional Law, 12(1)/2014, 136-163. 
For more than a decade after the judgment in Van Gend \& Loos was rendered, the notion of direct effect equalled the nowadays notion of vertical direct effect. ${ }^{10}$ Finally, the scope of application of this important principle of EU law was decisively broadened in Defrenne v. Sabena, ${ }^{11}$ the case renowned for providing for the first time an unambiguous and straightforward expression of intent, made by the CJEU regarding the establishment of what was later to become known as the horizontal direct effect of EU law. ${ }^{12}$ Practically simultaneously with Defrenne v. Sabena, the first sign of the same effect of the fundamental freedoms in the internal market were provided in the CJEU's case law. ${ }^{13}$ However, from then onwards the CJEU has not only demonstrated a different approach with regard to different freedoms but its judgments have been known to vary noticeably from one case to another, pursuing the protection of the exact same fundamental freedom. This altogether led to the emergence of some of the most challenging contemporary dilemmas regarding the interpretation and application of EU law, ${ }^{14}$ with one of those being the central issue of this paper.

10 Vertical direct effect is the legal concept according to which nationals of Member States can claim individual rights before the courts in the Member States originating directly from the provisions of EU law. For a more detailed elaboration of the origins and development of the principle of vertical direct effect, for instance, see M. Rasmussen, "How to enforce European law? A new history of the battle over the direct effect of Directives, 1958-1987" European Law Journal 23/2017, 290-308.

11 Case C-43/75, Gabrielle Defrenne v Société Anonyme Belge de Navigation Aérienne Sabena (8 April 1976) EU:C:1976:56.

12 Namely, unlike the Walrave \& Koch case (see infra note 23), in which the CJEU deliberately constrained the effect of the free movement of workers provisions to a very specific type of private parties, in Defrenne $v$ Sabena it explicitly stated with regard to Article 119 of the EEC (introducing the principle of equal pay between men and women) that there is "fundamental distinction to be drawn between Article 119 and the other provisions which the Court has held to be directly applicable" and finished off in the final order of the judgment with the notable statement according to which the national courts have a duty to ensure the protection of the rights that Article 119 EEC vests in the individuals, "in particular in the case of those forms of discrimination which have their origin in legislative provisions or collective labor agreements, as well as where men and women receive unequal pay for equal work which is carried out in the same establishment or service, whether private or public." For a more detailed elaboration and definition of the principle of horizontal direct effect, see A. Hartkamp, "The Effect of the EC Treaty in Private Law: On Direct and Indirect Horizontal Effects of Primary Community Law", European Review of Private Law 18(3)/2010, 527-548.

13 See ibid., Part 2.

14 See E. J. Lohse, "Fundamental Freedoms and Private Actors - towards an 'Indirect Horizontal Effect”" European Public Law 13(1)/2007, 159-190. 


\subsection{Aims and objectives}

As implied in its title, the aim of this paper is to establish whether and to what extent the TFEU provisions on free movement of goods apply to legal relations established between two or more private parties. To that end, an analysis of the relevant case law related to this particular issue is undertaken further below, i.e. in the third part of this paper. The analysis itself aims to support the initial hypotheses, hereinafter presented, that notwithstanding sporadic but only implicit inclination in its judgments towards establishing direct horizontal effect of the free movement of goods - the CJEU has constantly and resolutely abstained from recognizing the existence of such an effect, the same effect that it acknowledged decades ago regarding the free movement of workers and services. Based on the case law analysis, the conclusion is also offered that in terms of the recent developments in the field of free movement of goods, the CJEU has opted for further expansion of the concept of vertical direct effect in order to avoid establishing the horizontal direct effect on the freedom of movement of goods, at least for the time being, but still to protect it against certain impediments generated by private parties through linking their actions to Member States.

Before the focus is entirely turned to free movement of goods, part two of the paper provides an overview of the status quo regarding the horizontal direct effect of the free movement of workers, as well as of the free movement of services and right of establishment, which are fundamental freedoms recognized by most as having very limited but still evident horizontal direct effect. ${ }^{15}$ This was needed not only in order to provide the opportunity for comparisons, important in terms of understanding the differences in the CJEU's approach to different fundamental freedoms, but also to outline the general framework in which the horizontal direct effect of fundamental freedoms currently exists. On the other hand, the fourth and arguably the most specific fundamental freedom, ${ }^{16}$ the free movement of capital, remains outside the scope of the

15 There is still strong opposition, particularly so on the national level, to recognizing and accepting the concept of direct effect of the TFEU provisions establishing fundamental freedoms on relations between purely private parties. For instance, there is a fairly general consent in German jurisprudence that such an effect does not and should not exist. See ibid., 164.

16 To begin with, the freedom of capital movement had become operational considerably later than the other three - starting on 1 November 1993, when the Maastricht Treaty entered into force. Also, in comparison to other fundamental freedoms, another considerable difference would be that this fundamental freedom offers protection also to natural and legal persons from third countries, which makes the potential introduction of its horizontal direct effect additionally hazardous. See J. A. Usher, "The Evolution of the Free Movement of Capital”, Fordham International Law Journal 31(5)/2007, 1533-1570. 
paper, since there is a rather general consensus that this freedom has no horizontal effect. ${ }^{17}$

\section{A GLANCE AT THE BROADER PERSPECTIVE: THE HORIZONTAL DIRECT EFFECT OF FUNDAMENTAL FREEDOMS OTHER THAN FREE MOVEMENT OF GOODS}

\subsection{Further clarification of the principle of the horizontal direct effect}

In order to create the basis for the analyses and conclusions to follow, it is important to define more clearly the concept of the horizontal direct effect of the TFEU free movement provisions. ${ }^{18}$ In particular, this author finds that it is of fundamental importance to precisely frame, i.e. define, the notion of private party in this specific context, since the entire concept revolves around legal relations between such persons, both natural and artificial. To that end, formally private but de facto public entities, which are most noticeably private legal entities vested with the right of exercising specific public authority (jure imperii) and other entities, sometimes referred to as "emanations of the state", are not hereinafter considered private parties in the context of the horizontal direct effect, at least not when exercising such authority. ${ }^{19}$ Hence, the notion of private party is confined herein to that which could be termed "purely private party", which is generally in line with the legal reasoning followed by the CJEU itself in the cases related to the horizontal direct effect, as is evident from the analysis of case law presented hereinafter.

\subsection{The horizontal direct effect of the free movement of workers and free movement of services}

Regarding the free movement of workers and free movement of services, whereas the latter tends to generally include the right of establishment, ${ }^{20}$ one must first notice that the key judgments in cases

17 See, e.g.,V. Savković, "The Alleged Case of Golden Shares in Montenegro: A Candidate Country's Experience as an Incentive for Including Acta Jure Gestionis within the Range of Restrictions on Free Movement of Capital", Review of Central and East European Law 41(2)/2016, 117-156.

18 Though, it should be underlined that the CJEU itself never uses this term but rather refers to this concept by underlining that some provisions of EU law may be invoked by one private party against another. See C. Krenn, "A Missing Piece in the Horizontal Effect 'Jigsaw': Horizontal Direct Effect and the Free Movement of Goods", Common Market Law Review 49(1)/2012, 177-216, 178.

19 For a more detailed analysis of the notion of emanation of the state under the CJEU case law, for instance, see M. Wiberg, The EU Services Directive: Law or Simply Policy?, T.M.C. Asser Press, The Hague 2014, 141-147.

20 For the purposes of this paper the general notion of the free movement of services is understood broadly so as to include the right (i.e. freedom) of establishment, 
allowing the horizontal direct effect of these freedoms for the most part follow the same line of legal reasoning. ${ }^{21}$ It seems, though, that the free movement of workers had been the one freedom leading the way from the start. $^{22}$ Therefore, the focus will first be on the brief chronology of the key developments related to its horizontal direct effect.

It all started with Walrave \& Koch, ${ }^{23}$ the first and most notable case in which the horizontal direct effect of the free movement provisions was partially recognized by the CJEU. More precisely, the key statement made by the CJEU in its judgment was that the prohibition of discrimination on the basis of nationality between workers of the Member States "does not only apply to the action of public authorities but extends likewise to rules of any other nature aimed at regulating in a collective manner gainful employment and the provision of services." 24

After this initial precedent, an additional broadening of the horizontal effect of the free movement of workers provisions was seen in Bosman, ${ }^{25}$ after which both discriminatory and non-discriminatory legal instruments created by private parties, with the view to regulating gainful employment in a collective manner, were included within the range of impermissible restrictions on the free movement of workers. ${ }^{26}$

Further development regarding the horizontal direct effect of the free movement of workers was seen in Angonese. ${ }^{27}$ Namely, the court has

since these two are closely interlinked. Furthermore, even the CJEU often avoids drawing the line between the two and opts to simultaneously apply both rules, i.e. freedoms, particularly so in cases establishing the horizontal direct effect of these freedoms in specific cases (see A. Cuyvers, "Freedom of Establishment and the Freedom to Provide Services in the EU", East African Community Law: Institutional, Substantive and Comparative EU Aspects (eds. E. Ugirashebuja et al.), Brill, Leiden - Boston 2017, 376-391).

21 See J. Stuyck, "The European Court of Justice as a motor of private law", European Private Law (ed. C. Twigg-Flesner), Cambridge University Press, Cambridge 2010, 108. Such approach, of course, should be generally regarded as a sound practice, given the need for legal certainty in an important area of EU law, such as the establishment and protection of fundamental freedoms of the internal market. Regretfully so, this is not always the case in terms of other fundamental freedoms, as is demonstrated further below, in regard to the free movement of goods.

22 See, S. Robin-Oliver, "The evolution of direct effect in the EU: Stocktaking, problems, projections", International Journal of Constitutional Law 12(1)/2014, 165-188.

23 See Case C-36/74, B.N.O. Walrave and L.J.N. Koch v Association Union Cycliste Internationale, Koninklijke Nederlandsche Wielren Unie and Federación Española Ciclismo (12 December 1974) EU:C:1974:140.

24 Ibid., par. 17.

25 See Case C-415/93, Union Royale Belge des Sociétés de Football-Association ASBL v Jean-Marc Bosman (15 December 1995) EU:C:1995:463.

26 Ibid., par. 103.

27 See Case C-281/98, Roman Angonese v Cassa di Risparmio di Bolzano SpA 6 June 2000) EU:C:2000:296. 
taken the general position that abolition of obstacles to freedom of movement of persons constitutes a specific application of the general prohibition of discrimination by stating that "the prohibition of discrimination on grounds of nationality laid down in Article 48 [currently Article 45 TFEU] of the Treaty must be regarded as applying to private persons as well." 28 In doing so, the CJEU made it clear that it finds free movement of workers to be both vertically and horizontally effective. However, the question remained unanswered whether Article 45 TFEU is considered to produce direct effect on relations between private parties, if the measure contested for having a restrictive effect is not of discriminatory nature. This question, of course, did not concern the legal instruments created by private parties with the view to regulating gainful employment in a collective manner that was already considered by the court in Bosman as "eligible" for representing impermissible restrictions, notwithstanding the non-existence of discriminatory nature of the restriction.

The latest broadening of the scope of the non-discriminatory impermissible restrictions on free movement of workers was seen in Casteels, ${ }^{29}$ the case in which the CJEU added to that "circle" mandatory collective labor agreements, regulatory instruments of similar nature but nevertheless different than private regulation on gainful employment in a collective manner. However, arguably even more important development, with regard to Casteels, was the CJEU's long-anticipated direct statement "promising" the imposition of the full horizontal direct effect of Article 45 TFEU. Namely, in addition to rendering a decision regarding a particular set of circumstances, the court also stated that "Article 45 TFEU militates against any measure which, even though applicable without discrimination on grounds of nationality, is capable of hindering or rendering less attractive the exercise by European Union nationals of the fundamental freedoms guaranteed by the Treaty." ${ }^{30}$ Hence, apparently the CJEU has expressed its readiness to abandon the so-called doctrine of exceptions, which has been underlying the contemporary approach to the horizontal direct effect of fundamental freedoms since the very beginning. ${ }^{31}$

As for the free movement of services and right of establishment, as already mentioned, ${ }^{32}$ ever since Walrave $\&$ Koch, ${ }^{33}$ the CJEU has been

28 See Judgment in Angonese, par. 36.

29 See Case C-379/09, Maurits Casteels v British Airways plc. (10 March 2011) EU:C:2011:131.

30 Ibid., par. 22.

31 See H. Schepel, "Constitutionalising the Market, Marketising the Constitution, and to Tell the Difference: On the Horizontal Application of the Free Movement Provisions in EU Law”, European Law Journal 18(2)/2012, 177-200.

32 See supra note 19.

33 This case and the corresponding judgment established that both free movement of workers and freedom to provide services have direct horizontal effects regarding the 
recognizing their horizontal direct effect by utilizing identical or similar arguments, i.e. the same line of legal reasoning as in cases of free movement of persons. ${ }^{34}$ This trend has continued throughout the decades until several new precedents were observed recently, establishing particular "exceptions" in which the horizontal direct effect of the free movement of services and of the freedom of establishment is allowed. Most notably, these are Viking, ${ }^{35}$ a case dealing with the freedom of establishment, and Laval, ${ }^{36}$ the case that led to further extension of the horizontal direct effect of the free movement of services. In both cases the court included the collective actions of trade unions within the range of restrictions of these two freedoms. ${ }^{37}$ Also, in both of these cases the trade unions were acknowledged as genuine private entities which were acting within their rights and no direct or indirect link with Member States was established nor pursued by the Court.

\section{HORIZONTAL DIRECT EFFECT OF THE FREEDOM OF MOVEMENT OF GOODS? - ANALYSIS OF THE CASE LAW}

The freedom of movement of goods is the most controversial of the four fundamental freedoms of the internal market in terms of the (non-) existence of horizontal direct effect. As others would put it, the CJEU provided a few "glimpses" of the horizontal direct effect of the free movement of goods during the tribunal's early history, ${ }^{38}$ however, since than it repeatedly demonstrated its persistence in depriving this particular fundamental freedom of such effect, at least until some recent cases which reinvigorated old debates on the subject. However, first things first, let us proceed with the most relevant case law, in chronological order.

legal relations established under private rules, aimed at collectively regulating gainful employment and services.

34 See J. Stuyck, 108.

35 Case C-438/05, International Transport Workers' Federation and Finnish Seamen's Union v Viking Line ABP and OÜ Viking Line Eesti (11 December 2007) EU:C:2007:772.

36 Case C-341/05, Laval un Partneri Ltd vt Svenska Byggnadsarbetarefbsrbundet and Others (18 December 2008) EU:C:2007:809.

37 Still, it seems that the CJEU insisted on the existence of a direct link between the collective actions of the trade union and their endeavors to conclude collective agreements, regulatory instruments, which were earlier affirmed by the court as potential restrictions to free movement of persons and services. See R. van Leuken, 90-96. For further elaboration of these two cases, see C. Barnard, "Viking and Laval: An Introduction", Cambridge Yearbook of European Legal Studies 10/2008, 463-492.

38 See C. Krenn, 179; D. Vuletić, "Direct Horizontal Effect of the Free Movement of Goods and Reshaping of The European Economic Constitution. Back to the Future?", InterEULawEast 1(2)/2014, 53-70. 
The case that initially gave rise to debates on whether the CJEU finds that there is a horizontal direct effect of the free movement of goods provisions is Dansk Supermarked. ${ }^{39}$ The case was initiated by the motion for a preliminary ruling arising out of the dispute between two Danish companies, Imerco and Dansk Supermarked. Imerco ordered a contingent of china services to be retailed in Denmark exclusively by its subcontractors and made an agreement with a British manufacturer that it could sell the residual, i.e. substandard pieces, but not in Denmark or other Scandinavian countries. The British manufacturer honored its contractual obligation and sold the substandard pieces in Britain. However, some portion was acquired lately by Dansk Supermarked for the purpose of further retailing in Denmark. Since Dansk Supermarked refused to withdraw the goods from its stores, Imerco filed for an injunction based on the infringement of the Danish Law on Marketing, based on which the injunction sought was issued by the first instance court and confirmed by the appellate court. In its appeals, filed before the appellate court and the Supreme Court of Denmark, Dansk Supermarked relied on Article 30 EEC (Article 34 TFEU) establishing the freedom of movement of goods by prohibiting restrictions on imports and all measures of equivalent effect. Hence, the actual preliminary question put forward by the Supreme Court of Denmark before the CJEU was whether the provisions of the EEC Treaty, or measures in implementation thereof, preclude the application of the Danish laws on copyright, trademarks and marketing to the case ${ }^{40}$

In this well-known case, the "famous" statement made by the CJEU in its decision - the one that started the debates on the horizontal direct effect of the free movement of goods - was that "it is impossible in any circumstances for agreements between individuals to derogate from the mandatory provisions of the Treaty on the free movement of goods." Furthermore, the court added that "an agreement between individuals intended to prohibit the importation of such goods may not be relied upon or taken into consideration in order to classify the marketing of such goods as an improper or unfair commercial practice." ${ }^{42}$ Hence, apart from essentially finding that Article 30 of the EEC Treaty must be interpreted to mean that the implementation of Danish law may not prohibit that which is otherwise the recognized (allowed) exercise of the freedom of movement of goods, the CJEU seemingly implied its willingness to consider contractual agreements as potentially impermissible restrictions on free movement of goods in the internal market. However, as bluntly

39 Case 58/80, Dansk Supermarked A/S v. A/S Imerco (22 January 1981) EU:C:1981:17.

40 Ibid., par. 6.

41 Ibid., par. 17.

42 Ibid. 
put by Van Leuken, ${ }^{43}$ since the case was instigated with the motion for a preliminary ruling by the court on the subject of non-contractual liability, the issue of whether the court had introduced the horizontal direct effect remained open for further discussion.

Shortly after Dansk Supermarked, the CJEU rendered another decision which gave rise to debates on whether the freedom of movement of goods should join those fundamental freedoms for which (limited) horizontal direct effect had already been established. It was the ruling delivered in Buy Irish, ${ }^{44}$ i.e. an infringement procedure in which the Ireland was the party to the proceedings as the alleged infringer of its duty to uphold the free movement of goods in the internal market. More specifically, the case was provoked by the "Buy Irish" campaign that was conducted by an Irish company, effectively dominated by the Irish Government. Even the campaign, aimed at increasing the consumption of domestic products on account of the imported goods, was created and partially funded by the state. Hence, hardly surprisingly, the European Commission initiated procedure before the CJEU for the alleged breach of Article $30 \mathrm{EEC}$ (Article $34 \mathrm{TFEU}$ ) by the Ireland. Consequently, the court simply found in its final order that by organizing a campaign to promote the sale and purchase of Irish products within its territory, Ireland has failed to fulfill its obligations under Article 30 EEC (Article 34 TFEU). ${ }^{45}$ Before that, however, the court had found in the reasons of the judgment that, notwithstanding the fact that the campaign was entirely executed by a private company, the campaign, i.e. the restrictive measure involved, was attributable directly to a public entity, i.e. the Government of Ireland in that particular case. ${ }^{46}$

On the other hand, a considerably different set of circumstances, but essentially the same doctrinal approach of the CJEU, was seen in Spanish strawberries, ${ }^{47}$ another famous free movement of goods case. Namely, in an infringement procedure initiated by the European Commission against France, the CJEU had to decide on whether passivity of the French Government, in regard to the roadblocks and other violent protest actions by French farmers directed against agricultural products from Spain, may be considered violation of its duties under the TFEU free movement provisions. The court simply - and rightfully so - found that by failing to undertake all necessary and proportionate measures, in

43 See R. van Leuken, 120.

44 Case 249/81, Commission of the European Communities $v$ Ireland (24 November 1982) EU:C:1982:402.

45 Ibid., final order of the judgment.

46 Ibid., par 29.

47 Case C-265/95, Commission of the European Communities v French Republic (9 December 1997) EU:C:1997:595. 
order to prevent the free movement of fruit and vegetables from being obstructed by actions of private individuals, the French Government had failed to fulfill its obligations under the TFEU free movement provisions. ${ }^{48}$ Hence, although occurring in a considerably different context, the CJEU once again found a way to hold a Member State responsible for actions of private actors obstructing the free movement of goods in the internal market.

In following the above approach, the CJEU demonstrated that which was slowly becoming a pattern in its case law - and not only in terms of the freedom of movement of goods. Namely, it would rather gradually expand the notion of public entity and the range of its duties under the freedom of movement of goods regime, than "venture" into drawing clear borderlines between public and private law instruments, which would probably speed up the establishing of the horizontal direct effect in the case of this fundamental freedom.

Further demonstration of the CJEU's reluctance to introduce the horizontal direct effect of the freedom of movement of goods was witnessed in the streak of cases decided by this tribunal since the mid$1980 \mathrm{s.}^{49}$ It is the opinion of this author, aside from some of the above described cases which the European Commission brought against different Member States, in which the CJEU merely indirectly implied its reluctance to accord the direct horizontal effect to free movement of goods provisions, the said streak involves two types of cases. The first type includes those cases in which preliminary questions actually concerning purely private law instruments, as potentially impermissible restrictions to free movement of goods, were raised before the CJEU. Such are the cases Haug-Adrion, ${ }^{50}$ Bayer AG et al. v. Süllhöfer, ${ }^{51}$ and VZW Vereniging van Vlaamse Reisbureaus. ${ }^{52}$ In Haug-Adrion, the court simply avoided examining private law instrument against the free movement of goods provisions, while at the same time examining them against the TFEU (EEC) provisions on free movement of persons and free movement of services. On the other hand, it examined national legislation, based on which the contested private law instrument was adopted (general terms and conditions of an insurance company) against provisions on the free movement of goods, which was a clear indication that the CJEU finds the

48 Ibid., final order of the judgment.

49 See L. W. Gormley, "Private Parties and the Free Movement of Goods: Responsible, Irresponsible, or a Lack of Principles?” Fordham International Law Journal 38(4)/2015, 992-1016; See R. van Leuken, 115 - 127.

50 Case 251/83, Eberhard Haug-Adrion v Frankfurter Versicherungs-AG (13 December 1984) EU:C:1984:397.

51 Case 65/86, Bayer AG et al. v. Süllhöfer (27 September 1988) EU:C:1988:448.

52 Case 311/85, VZW Vereniging van Vlaamse Reisbureaus v. VZW Sociale Dienst van de Plaatselijke en Gewestelijke Overheidsdiensten (1 October 1987) EU:C:1987:418. 
particular private law instrument not to have a horizontal direct effect. The court proceeded similarly in Bayer AG et al. v. Süllhöfer. Finally, in VZW Vereniging van Vlaamse Reisbureaus the CJEU clarified its already evident position, by expressly stating that it finds the freedom of movement of goods to concern exclusively public measures as potential restrictions. ${ }^{53}$

The second type of cases includes those in which the subject matter was not whether a given private law instrument should be considered as an impermissible restriction on the free movement of goods. On the contrary, the issue was whether provisions belonging to the body of public law could be considered as impermissible restriction on free movement of goods in the internal market, but the court nevertheless made explicit remarks on the TFEU (EEC) free movement of goods provisions, in which it reiterated its standpoint: these rules apply to public measures and not to the conduct of undertakings and private actors in general. Such were the cases Jan van de Haar and Kaveka de Meern BV $V^{54}$ and Sapod Audic v. Eco-Emballages $S A .{ }^{55}$

Finally, we come to Fra.bo, ${ }^{56}$ a much debated case, ${ }^{57}$ as well as the latest among the cases that gave rise to expectations that the freedom of movement of goods may be accorded horizontal direct effect in the near future. In a prelude to this already famous case, Fra.bo SpA, an Italian company producing copper fittings for water pipes, found itself dissatisfied for not managing to meet the standards adopted by German company (DVGW), authorized under the German law to prescribe them and issue compliance certificates as de facto preconditions to entering the German market. This caused the litigation which led to the motion for a preliminary ruling on the issue of whether the activities of DVGW, in such legislative and regulatory context, represent restrictions on free movement of goods.

Unlike some previous cases involving companies or organizations (seemingly) belonging to private sectors, ${ }^{58}$ the CJEU explicitly recognized

53 Ibid., par 30.

54 Joined cases 177 and 178/82, Criminal proceedings against Jan van de Haar and Kaveka de Meern BV (5 April 1984) EU:C:1984:144, see par. 11 and 12.

55 C-159/00, Sapod Audic v Eco-Emballages SA (6 June 2002) EU:C:2002:343, see par. 74 .

56 Case C-171/11, Fra.bo SpA v Deutsche Vereinigung des Gas-und Wasserfaches eV $(D V G W)$ - Technisch-Wissenschaftlicher Verein (12 July 2012) EU:C:2012:453.

57 For instance, see A.C. van de Kooij, "The Private Effect of the Free Movement of Goods: Examining Private-Law Bodies' Activities under the Scope of Article 34 of the Treaty of the Functioning of the European Union", Legal Isues of Economic Integration 40(4)/2013, 363-374; H. van Harten, T. Nauta, "Towards Horizontal Direct Effect for the Free Movement of Goods? Comment on Fra.bo" European Law Review 38(5)/2013, 677-694.

58 Most notably, Buy Irish. 
the company allegedly imposing restrictions as "a non-profit, private law body whose activities are not financed by the Federal Republic of Germany." ${ }^{59}$ Moreover, it also established that Germany has no decisive influence over its standardization and certification activities. ${ }^{60}$

On the other hand, the CJEU also established the following. First, German legislature assumes that products certified by DVGW are compliant with national legislation. ${ }^{61}$ Second, DVGW was the only body offering the possibility for obtaining a compliance certificate in this case. ${ }^{62}$ Third, since German consumers were strongly relying on this certificate, obtaining it was a de facto precondition for entering the German market. ${ }^{63}$ Correspondingly, it was concluded by the tribunal that "Article 28 EC must be interpreted as meaning that it applies to standardization and certification activities of a private-law body, where the national legislation considers the products certified by that body to be compliant with national law and that has the effect of restricting the marketing of products which are not certified by that body." 64

In the opinion of this author, what the CJEU actually did in Fra.bo was what it has been doing in the past decades, particularly so in terms of interpretation and implementation of the freedom of movement of goods. By resorting once again to creative interpretation, it opted to bring justice, while at the same time avoiding to introduce radical changes to contemporary EU law. ${ }^{65}$ In doing so, the CJEU simply further expanded the concept of the vertical direct effect of the TFEU provisions on free movement of goods by broadening the notion of impermissible state measures, i.e. restriction on the free movement of goods. As for the scope of the expansion, it could be argued that its extent is quite significant, meaning that the freedom of movement of goods after Fra.bo could potentially apply to any private body capable of hindering free movement of goods in a near-identical manner to that of the Member States, but it could also be argued that the expansion was limited to merely one additional and quite specific set of circumstances. Put differently, since it was the first significant development regarding the effect of the free movement of goods provisions on legal relations between the private

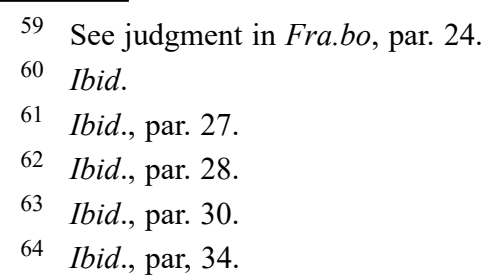

65 This is, of course, not to imply that the court lacked courage to shape EU law with occasional precedents introducing new legal concepts and new legal principles created in order to make the existing body of EU law more complete and efficient (see supra note 1). 
parties in decades, it is quite understandable that there are authors perceiving Fra.bo as an announcement of the "horizontal shift" in the CJEU's policy towards the scope of the application of the free movement of goods provisions. ${ }^{66}$ However, this author belongs to those who believe the decision in Fra.bo to be just another carefully taken step by the CJEU in expanding the concept of the vertical direct effect in terms of the free movement of goods. ${ }^{67}$ The fact that the greatest efforts of the Court were once again invested in establishing the existence of de facto public nature (and status) of the involved private company seems to strongly support for such standpoint.

Finally, the above findings concerning Fra.bo case should also be viewed in light of the most recent cases in which the horizontal direct effect has been established with regard to other fundamental freedoms, such as are the already elaborated cases Viking, Laval or Casteels. Namely, unlike Fra.bo, the CJEU did not establish any links between the private actors creating restrictions to free movement nor did it pursue them in these cases. This demonstrates that the difference still exists in the tribunal's approach to whether free movement of goods applies directly to legal relations of (purely) private parties, which prima facie implies that the CJEU may still not be ready to accord horizontal direct effect to this particular freedom. However, the findings of this author slightly differ.

It has been noticed that the CJEU's motives for not according horizontal direct effect to freedom of movement of goods remain unclear, ${ }^{68}$ which gives rise to numerous speculations on what could be the reasons, as well as how it should be proceeded in terms of implementation criteria and should the court move forward with establishing such an effect. ${ }^{69}$ On the other hand, as explained in the first part, it was not the aim of this paper to establish the said reasons or make proposals on how the court should proceed in light of the present dilemma. The aim was to diligently review the case law on the issue, as well as to

66 R. van Leuken, 128; H. Schepel, "Freedom of Contract in Free Movement Law: Balancing Rights and Principles in European Public and Private Law" European Review of Private Law 21(5/6)/2013, 1211-1230, 1214; H. van Harten, T. Nauta, 677-694.

67 See C. Baranard, The Substantive Law of the EU. The Four Freedom, Oxford University Press, Oxford 2016, 77; F. Weiss, C. Kaupa, European Union Internal Market Law, Cambridge University Press, Cambridge 2014, 47; D. Chalmers, G. Davies, G. Monti, European Union Law, Cambridge University Press, Cambridge 2014, 770; C. Krenn, 181.

68 For instance, see A.C. van de Kooij, 367.

69 For instance, see D. Waytt, "Horizontal Effect of Fundamental Freedoms and the Right to Equality after Viking and Mangold, and the Implications for Community Competence", Croatian Yearbook of European Law \& Policy 4/2008, 1-48; R. van Leuken, 125-132; D. Vuletić; A.C. van de Kooij; C. Krenn. 
compare it with the tribunal's ratio decidendi in the case law, recognizing the horizontal direct effect of other fundamental freedoms, in order to provide firm grounds for conclusions on the (non-)existence of the same effect with regard to free of movement of goods and the corresponding standpoint of the CJEU. Nevertheless, based on the case law analyses provided above, the following conclusion seems to be well-founded.

Until today, the cases presenting the CJEU with the opportunity for establishing the horizontal effect of the free movement of goods were simply not as challenging as were those involving free movement of workers and services. Put differently, it would seem that, regarding the free movement of goods, the court lacked the same "incentive" to venture into establishing its horizontal direct effect. Therefore, although involving different fundamental freedoms, the cases analyzed in the second part of the paper - such as Walrave \& Koch, Angonese, Castels, Viking or Laval - may also be viewed as an indication that, should the occasion arise in which there would be no other way to rationalize its view that a given private party had created an impermissible restriction on free movement of goods, the CJEU could resort to recognizing the horizontal direct effect of this fundamental freedom. Moreover, despite representing an example of the Court's creativeness in avoiding the introduction of the horizontal direct effect by expanding the notion of the vertical direct effect of the free movement of goods, the Fra.bo case could also be legitimately regarded as a "step towards the inevitable." Namely, in addition to the aforesaid, this case also has demonstrated how far the CJEU is prepared to go in order not to permit a measure that it finds to be an impermissible restriction on the free movement of goods to be allowed to withstand.

\section{CONCLUSION}

According to the analyses presented in this paper, the CJEU still doesn't recognize the horizontal direct effect of the free movement of goods. Namely, despite the lack of clarity in its earliest cases, since then, the court has been explicit in this regard on more than a few occasions and we are yet to witness an even remotely explicit withdrawal from such a position. On the other hand, in the above discussed Fra.bo case - the most recent one related to the issue - the court did find that a "privatelaw body" can impose restrictions on free movement of goods that are impermissible from the standpoint of EU law. However, although admitting that German company DVGW is a private body, the court put forth a very strong effort to establish that this private body was put in the position - to a large extent by the German state itself - of a de facto public body. In doing so, the court demonstrated hesitation to move away from its decades old position that the freedom of movement of goods concerns public measures and not the conduct of undertakings and private 
actors in general. Therefore, it would seem that the CJEU still prefers expanding the concept of the vertical direct effect of the TFEU free movement of goods provisions to recognizing their horizontal direct effect.

On the other hand, the conclusion was also put forward in this paper that both the case law recognizing the existence of the horizontal direct effect of other fundamental freedoms, as well as the Fra.bo case, which further expanded the boundaries of the vertical direct effect of the free movement of goods, may very well be regarded as indication of the CJEU's preparedness to reconsider its longstanding position on (non-) recognition of the horizontal direct effect of the free movement of goods. Of course, provided that the "right opportunity" presents itself in the foreseeable future.

\section{REFERENCES}

Arnull, A., "The European Court and Judicial Objectivity: A Reply to Professor Hartley", The Law Quarterly Review 112/1996.

Baranard, C., The Substantive Law of the EU. The Four Freedom, Oxford University Press, Oxford 2016.

Barnard, C., "Viking and Laval: An Introduction", Cambridge Yearbook of European Legal Studies 10/2008.

Blauberger, M., Schmidt, S. K., "The European Court of Justice and its political impact", West European Politics 40(4)/2017.

Chalmers, D., Davies, G., Monti, G., European Union Law, Cambridge University Press, Cambridge 2014.

Cuyvers A., "Freedom of Establishment and the Freedom to Provide Services in the EU", East African Community Law: Institutional, Substantive and Comparative EU Aspects (eds. E. Ugirashebuja et al.), Brill, Leiden - Boston 2017.

De Freitas, L. V., "The Judicial Activism of the European Court of Justice", Judicial Activism: An Interdisciplinary Approach to the American and European Experiences (eds. L. P. Coutinho, M. La Torre, S. D. Smith), Springer International Publishing, Cham Heidelberg 2015.

De Mol, M., "Kücükdeveci: Mangold Revisited - Horizontal Direct Effect of a General Principle of EU Law: Court of Justice of the European Union (Grand Chamber) Judgment of 19 January 2010, Case C-555/07", European Constitutional Law Review 6(2)/2010.

De Waele, H., "The Role of the European Court of Justice in the Integration Process: A Contemporary and Normative Assessment", Hanse Law Review 6(1)/2010. 
Gormley, L. W., "Private Parties and the Free Movement of Goods: Responsible, Irresponsible, or a Lack of Principles?" Fordham International Law Journal 38(4)/2015.

Hartkamp, A., "The Effect of the EC Treaty in Private Law: On Direct and Indirect Horizontal Effects of Primary Community Law", European Review of Private Law 18(3)/2010.

Hartley, T. C., "The European Court, Judicial Objectivity and the Constitution of the European Union", The Law Quarterly Review 112/1996.

Lohse, J. E., "Fundamental Freedoms and Private Actors - towards an 'Indirect Horizontal Effect'“, European Public Law 13(1)/2007.

Krenn, C., "A Missing Piece in the Horizontal Effect 'Jigsaw': Horizontal Direct Effect and the Free Movement of Goods", Common Market Law Review 49(1)/2012.

Mayr, S., "Putting a Leash on the Court of Justice? Preconceptions in National Methodology v Effet Utile as a Meta-Rule", European Journal of Legal Studies 5(2)/2012.

Muir, E., Dawson, M., De Witte, B., "Introduction: The European Court of Justice as a Political Actor", Judicial Activism at the European Court of Justice (eds. M. Dawson, B. de Witte, E. Muir), Edward Elgar Publishing, 2017.

Rasmussen, M., "Revolutionizing European law: A History of the Van Gend en Loos Judgment", International Journal of Constitutional Law 12(1)/2014.

Rasmussen, M., "How to enforce European law? A new history of the battle over the direct effect of Directives, 1958-1987", European Law Journal 23/2017.

Robin-Oliver, S., "The Evolution of Direct Effect in the EU: Stocktaking, Problems, Projections", International Journal of Constitutional Law 12(1)/2014.

Sadl, U., "The Role of Effet Utile In Preserving the Continuity and Authority of European Union Law: Evidence From the Citation Web of the Pre-accession Case Law of the Court Of Justice of the EU”, European Journal of Legal Studies 8(1)/2015.

Savković, V., "The Alleged Case of Golden Shares in Montenegro: A Candidate Country's Experience as an Incentive for Including Acta Jure Gestionis within the Range of Restrictions on Free Movement of Capital", Review of Central and East European Law 41(2)/2016.

Schepel, H., "Constitutionalising the Market, Marketising the Constitution, and to Tell the Difference: On the Horizontal Application of the Free Movement Provisions in EU Law", European Law Journal $18(2) / 2012$. 
Schepel, H., "Freedom of Contract in Free Movement Law: Balancing Rights and Principles in European Public and Private Law", European Review of Private Law 21(5/6)/2013.

Shapiro, M., "The European Court of Justice", The Evolution of EU Law (eds. P. Craig, G. De Búrca), Oxford University Press, Oxford 1999.

Storey, T., Turner, C., Unlocking Company Law, Routledge, Abingdon, Oxon - New York 2014

Stuyck, J., "The European Court of Justice as a motor of private law", European Private Law (ed. C. Twigg-Flesner), Cambridge University Press, Cambridge 2010.

Tridimas, T., "The Court of Justice and Judicial Activism", European Law Review 21/1996.

Usher, J. A., "The Evolution of the Free Movement of Capital", Fordham International Law Journal 31(5)/2007.

Van Harten, H., Nauta, T., "Towards Horizontal Direct Effect for the Free Movement of Goods? Comment on Fra.Bo", European Law Review 38(5)/2013.

Van de Kooij, A. C., "The Private Effect of the Free Movement of Goods: Examining Private-Law Bodies' Activities under the Scope of Article 34 of the Treaty of the Functioning of the European Union", Legal Issues of Economic Integration 40(4)/2013.

Van Leuken, R., Private Law and the Internal Market. Direct Horizontal Effect of the Treaty Provisions on Free Movement, Intersentia, Cambridge 2017.

Vuletić, D., "Direct Horizontal Effect of the Free Movement of Goods and Reshaping of the European Economic Constitution. Back to the Future?", InterEULawEast 1(2)/2014.

Waytt, D., "Horizontal Effect of Fundamental Freedoms and the Right to Equality after Viking and Mangold, and the Implications for Community Competence", Croatian Yearbook of European Law \& Policy 4/2008.

Weiler, J. H. H., "The Court of Justice On Trial”, Common Market Law Review 24/1987.

Weiss, F., Kaupa, C., European Union Internal Market Law, Cambridge University Press, Cambridge 2014.

Wiberg, M., The EU Services Directive: Law or Simply Policy?, T.M.C. Asser Press, The Hague, 2014.

Article history:

Received: 1. 9. 2018. Accepted: 29. 11. 2018. 